\title{
FAUNA OF PROTECTED AREAS - 19: HERPETOFAUNA OF NALLAMALAI HILLS WITH ELEVEN NEW RECORDS FROM THE REGION INCLUDING TEN NEW RECORDS FOR ANDHRA PRADESH
}

\author{
K. Thulsi Rao', H.V. Ghate ${ }^{2}$, M. Sudhakar ${ }^{1}$, S.M. Maqsood Javed ${ }^{1}$ and I. Siva Rama Krishna ${ }^{1}$ \\ ${ }^{1}$ Ecological Research \& Monitoring Laboratories, Nallamalai Hill Ranges, Eastern Ghats, Project Tiger Circle, Srisailam, Kurnool Dist., \\ Andhra Pradesh 518102, India; ${ }^{2}$ Department of Zoology, Modern College, Pune, Maharashtra 411005, India \\ Email :1 thulsirao@yahoo.co.ins
}

web supplement

\begin{abstract}
An inventory of herpetofauna of Nallamalai hills of Eastern Ghats in Andhra Pradesh, revealed that the region contains at least 18 species of amphibians belonging to 11 genera, distributed in 4 families and 48 species of reptiles belonging to 34 genera, distributed in 12 families, out of which eleven new records from the region including ten new records for the state.
\end{abstract}

\section{KEYWORDS \\ Eastern Ghats, habitat preference, herpetofauna, inventory, Nallamalai Hills}

AbBreviations

NSTR - Nagarjunasagar Srisailam Tiger Reserve; GBM Gundlabramheshwaram Wildlife Sanctuary; A.P. - Andhra Pradesh.

The present herpetofaunal studies were extensively carried out from November 2001 to September 2004 by us under 'All Taxa Biodiversity Inventory (ATBI)', to know the faunal diversity of three protected areas of Nallamalais - an offshoot of the Central Eastern Ghats of Andhra Pradesh. The herpetofauna of the Protected Areas of this region is poorly documented. Although, Sarkar et al. (1993), and Sanyal et al. (1993) have documented the known herpetofaunal resources of the state the information gaps with respect to the protected areas of Andhra Pradesh still exists (Srinivasulu, 2004). Now the present herpetofaunal studies give the precise information about their occurrence and habitat information for proper management and conservation of these species as part of management of the protected areas.

STUdy AREA

The study area (Fig - 1) Nallamalais $\left(14^{0} 26^{\prime}-16^{0} 31^{\prime} \mathrm{N} \& 78^{0} 30^{\prime}-\right.$ $80^{\circ} 10^{\prime} \mathrm{E}$ ) includes three protected areas of Andhra Pradesh, namely the Nagarjunasagar-Srisailam Tiger Reserve (N-STR) $\left(3,568 \mathrm{~km}^{2}\right)$, the Gundla Brahmeshwaram Wildlife Sanctuary (GBM) $\left(1,194 \mathrm{~km}^{2}\right)$ and the Rollapadu Wildlife Sanctuary $\left(9.37 \mathrm{~km}^{2}\right)$; covering five districts (Kurnool, Prakasam, Mahaboobnagar, Guntur \& Nalgonda). Mostly, N-STR and GBM have hilly terrain with plateaus, ridges, gorges and deep valleys which support tropical dry mixed deciduous forests with an under growth of grass and bamboo, while the Rollapadu Wildlife Sanctuary is an open grassland habitat. The vegetation is typical southern tropical mixed dry deciduous and southern tropical semi moist deciduous forest types intermingled with scrub (Champion \& Seth, 1968). The climate is generally hot and dry with maximum temperatures rising up to $45^{\circ} \mathrm{C}$ during May and drops down to $15^{\circ} \mathrm{C}$ in December. Average rainfall in this region is between $900-1000 \mathrm{~mm}$ and the average altitude is about $500 \mathrm{~m}$ with highest peak reaches up to $917 \mathrm{~m}$ (Durgam Konda) while the lowest is about $100 \mathrm{~m}$ (River Krishna).

\section{Material and Methods}

Faunal inventory surveys were conducted in different habitats like open dry scrub forest, mixed thorny dry deciduous forest, dry evergreen forest, grasslands, bamboo forest and riparian patches inside the three protected areas. Some species were hand collected; the snake stick was used for catching snakes. Some species were not collected and are to be treated on record as "sighting only". All the voucher specimens, except Indian Rock Python (Python molurus), Dog-faced Water Snake (Cerberus rhynchops) and Checkered Keel back (Xenochrophis piscator) were deposited (wet preserved) in Eco-Research and Monitoring Laboratories, Project Tiger, Srisailam. For wet preservation the animals were poisoned with an overdose of chloroform and then properly dissected and preserved in $10 \%$ formalin solution for over 24 to 48 hours. After fixation the specimens were washed thoroughly in water and stored in $70 \%$ ethyl alcohol. Reptile species were identified with the help of Fauna of British India volumes by Smith (1935, 1943). Latest names of snakes are from Whitaker and Captain (2004). Amphibians were identified on the basis of keys and descriptions in Boulenger (1890), Daniel (1963, 1975), Dutta (1997), Daniels (1997), Dubois and Ohler (1999), and Chanda (2002). Wherever possible the latest nomenclature is adopted.

\section{Results AND Discussion}

There is very little information about amphibian and reptilian fauna of the protected area network of Andhra Pradesh. Murthy (1968) recorded six species of amphibians from Nagarjuna valley of Andhra Pradesh which is now submerged under Nagarjunasagar Reservoir. Besides these, some scattered records by Boulenger (1890), Parker (1934), Pillai and Murthy (1982), Inger and Dutta (1986), Sekar (1991), Sarkar, et al. (1993), Dutta (1997), and Chanda (2002) are available. Sharma (1971) recorded 34 species of reptiles from Nagarjunasagar (a very small part of present N-STR) and besides some scattered records by Annandale (1906), Boulenger (1890), Daniel (1963, 1975, 2002), Murthy (1968, 1986), Sharma (1971), Sanyal et al. (1993) and Smith's works on the reptile fauna of India $(1931,1935,1943)$. Only a few previous published records Sanyal et al. (1993) and Sarkar et al. (1993) on the herpetofauna of this region are available. Stray records of publications outside the Nallamalais reveal a total of 42 species of herpetofauna (Srinivasulu, 2004), which constitutes a small part of the region. 
So far 18 species of amphibians belonging to 11 genera, distributed in four families and 48 species of reptiles belonging to 34 genera, distributed in 12 families have been recorded from the present study area. Out of this 11 new records from the region including 10 new records for the state are reported from this study. Since this is an inventory-based survey of herpetofauna, exhaustive references and synonymy of the various species is not attempted. Only names of the identified species, habitat preference, specimen codes and actual localities from where species were collected within the three protected areas are given (Tables $1 \& 2$ ) along with available photo plates (Images $1-59^{\mathrm{w}}$ ). This is a preliminary report and detailed studies regarding other parameters like individual species ecology, threats and status will be presented after completion of the studies.

The habitats and micro habitats of the species, which are first record for the state, were recorded during the study. Amphibians like Kaloula taprobanica, Uperodon globulosus and Tomopterna rolandae were found to be nocturnal, present in a variety of terrestrial habitats, near water bodies and also seen near human settlements. But Rana temporalis was found in torrents, living in streams with rocky bottom and boulders in the dense forest, while Polypedates leucomystax was arboreal, found in dry deciduous scrub to dense forest. Reptiles like Lygosoma guentheri, Mabuya beddomii, Sibynophis subpunctatus and Liopeltis calamaria were ground dwelling, while Ahaetulla nasutus isabellinus was arboreal and found in various moist habitats in the dry deciduous scrub to dense forest.

This report indicates that the area is rich and must contain many more species of amphibians and reptiles. Occurrence of some frogs like Painted Kaloula (Kaloula taprobanica) and Balloon Frog (Uperodon globulosus) is also interesting, so also of the snakes like Liopeltis and Cantor's Black-headed Snake (Sibynophis subpunctatus) and skinks like Lygosoma guentheri and Mabuya beddomii. Names marked with a single asterisk (*) denote new record from the Nallamalai region and two asterisks $(* *)$ denote new record from the state.

\section{REFERENCES}

Annadale, N. (1906). Notes on the Indian Tortoises. Journal of the Asiatic Society of Bengal 2: 203-206.

Boulenger, G.A. (1890). The Fauna of British India including Ceylon and Burma. Reptilia Batrachia. Taylor and Francis, London.

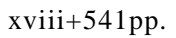

Champion, H.G. and S.K. Seth (1968). A Revised Survey of the Forest types of India. Govt. of India, Delhi, 404pp.

Chanda, S.K. (2002). Handbook: Indian Amphibians. Zoological Survey of India, Calcutta.

Daniel, J.C. (1963). Field guide to the amphibians of western India. Parts 1 \& 2. Journal of the Bombay Natural History Society 60(1): 415438); 690-702.

Daniel, J.C. (1975). Field guide to the amphibians of western India. Part 3. Journal of the Bombay Natural History Society 72: 506-522.

Daniel, J.C. (2002). The Book of Indian Reptiles and Amphibians. Bombay Natural History Society, viii+236pp.

Daniels, R.J.R. (1997). A field guide to the frogs and toads of the Western Ghats of India. Parts I to III. Cobra 27: 1-25; 28: 1-24; 29: 113.
Dubois, A. and A. Ohler (1999). Asian and Oriental toads of the Bufo melanostictus, B. Scaber and B. stejnegeri groups (Amphibia, Anura): A list of available names and valid names and redescription of some name bearing types. Journal of the South Asian Natural History 4: 133-180. Dutta, S.K. (1997). Amphibia of India and Sri Lanka (Checklist ad Bibliography). Odyssey Publishing House, Bhubaneswar, Orissa. xxii+342pp.

Inger, R.F. and S.K. Dutta (1986). On overview of Amphibian fauna of India. Journal of the Bombay Natural History Society 83: 135-146. Murthy, T.S.N. (1968). Notes on collection of amphibians from Nagarjuna Valley (Andhra Pradesh) with one new record. Journal of the University of Poona 34: 63-71.

Murthy, T.S.N. (1986). Lizards of Kurnool district. Bulletin of the Maryland Herpetological Society 22(3): 134-143.

Murthy, T.S.N. (1990). A Field Book of the Lizards of India. Records of the Zoological Survey of India 115: 92pp+24pl.

Parker, H.W. (1934). An Monography of the Frogs of the Family Microhylidae. Trustees of British Museum, London, viii+208pp+67figs. Pillai, R.S. and T.S.N. Murthy (1982). Herpetofauna of Eastern Ghats. Proceedings of the Seminar Resources Eastern Ghats: 81-84.

Sanyal, D.P., B. Datta Gupta and N.C. Gayen (1993). Reptilia, State Fauna series 5, Fauna of Andhra Pradesh, Part - I: 1-63, Zoological Survey of India, Calcutta.

Sarkar, A.K., P.K. Chandra and S. Ray (1993). Amphibia, State Fauna series 5, Fauna of Andhra Pradesh, Part-I: 65-87. Zoological Survey of India, Calcutta.

Sekar, A.G. (1991). Distribution of the Amphibian Fauna of India. Journal of the Bombay Natural History Society 88(1): 125-127.

Sharma, R. C. (1971). The Reptile Fauna of Nagarjunasagar dam area (Andhra Pradesh, India). Records of the Zoological Survey of India 63(1-4): 77-93.

Smith, M.A. (1931). The Fauna of British India, including Ceylon and Burma. Reptilia and Amphibia. Vol. I. Loricata, Testudines. Taylor and Francis, London, 185pp.

Smith, M.A. (1935). Fauna of British India including Ceylon and Burma. Reptila and Amphibia, Vol. II, Sauria. Today and Tomorrow's Printers \& Publishers, New Delhi, Indian Reprint (1974), 440pp.

Smith, M.A. (1943). Fauna of British India including Ceylon and Burma. Reptila and Amphibia, Vol. III Serpentes. Today and Tomorrow's Printers \& Publishers, New Delhi, Indian Reprint (1981), 583pp.

Srinivasulu, C. and B. Srinivasulu (2004). Herpetofaunal diversity of Rollapadu Wildlife Sanctuary and its vicinity, Andhra Pradesh, 5260pp. In: Proceedings of National symposium on Bioresourses, Biotechnology and Bioenterprises, 2003, Dept. of Zoology, Osmania University, Hyderabad.

Whitaker, R. and A. Captain (2004). Snakes of India: The Field Guide. Draco Books, Chennai, 481pp.

\section{ACKNOWLedgement}

The authors are very much thankful to Sri S.K. Das, IFS, Prl. Chief Conservator of Forests, Sri Hitesh Malhotra, IFS, Addl. Prl. Chief Conservator of Forests (WL), Sri A.V. Joseph, IFS, Chief Conservator of Forests (WL) A.P, Hyderabad and M. Prudhvi Raju, IFS, Conservator of Forests (Social Forestry), Vijayawada for constant encouragement and sustained support. We are also grateful to Dr Rajesh Gopal, IFS, Inspector General of Forests and Director Project Tiger and the MoEF, New Delhi for their consistent funding support and encouragement. We gratefully acknowledge our thanks to Dr. D.B. Bastawade, Assistant Zoologist, Z.S.I, WRS, Pune and Principal Modern College. We are also thankful to Mr. Ashok S. Captain for identification of some difficult snake species, Mr. Anand D. Padhye and Mr. Satish S. Kamble for identification of amphibians.

${ }^{\mathrm{w}}$ See images of herpetofauna from N-STR online as web supplement at www.zoosprint.org 
Table 1. List of Amphibians recorded from Nallamalais, Eastern Ghats, Andhra Pradesh

\begin{tabular}{|c|c|c|c|c|c|}
\hline Family & Taxon & Common Name & $\begin{array}{l}\text { Voucher } \\
\text { Specimen Code }\end{array}$ & $\begin{array}{l}\text { Habitat } \\
\text { Preference }\end{array}$ & Locality Code \\
\hline Bufonidae & $\begin{array}{l}\text { Bufo melanostictus (Schneider) } \\
\text { Bufo scaber * (Schneider) } \\
\text { Bufo stomaticus (Lutken) }\end{array}$ & $\begin{array}{l}\text { Common Indian Toad } \\
\text { Ferguson's Toad } \\
\text { Marbled Toad }\end{array}$ & $\begin{array}{l}\text { ERMA-1a } \\
\text { ERMA-5a } \\
\text { ERMA-18a }\end{array}$ & $\begin{array}{l}\mathrm{AH} \\
\mathrm{DF}, \mathrm{BP} \\
\mathrm{GL}\end{array}$ & $\begin{array}{l}\text { In all localities } \\
10 \\
13\end{array}$ \\
\hline Microhylidae & $\begin{array}{l}\text { Kaloula taprobanica** (Parker) } \\
\text { Microhyla ornata (Duméril \& Bibron) } \\
\text { Microhyla rubra (Jerdon) } \\
\text { Uperdon globulosus }{ }^{* *} \text { (Günther) } \\
\text { Uperodon systoma* }(\text { Schneider) }\end{array}$ & $\begin{array}{l}\text { Painted Kaloula } \\
\text { Ornate Microhylid } \\
\text { Narrow Mouthed Frog } \\
\text { Balloon Frog } \\
\text { Marbled Balloon Frog }\end{array}$ & $\begin{array}{l}\text { ERMA-4a } \\
\text { ERMA-8a } \\
\text { ERMA-6a } \\
\text { ERMA-7a } \\
\text { ERMA-2a }\end{array}$ & $\begin{array}{l}\text { SF,DF } \\
\text { SF,GL } \\
\text { SF,OF } \\
\text { SF,BP } \\
\text { AH }\end{array}$ & $\begin{array}{l}2,3,6,7 \& 8 \\
6,13 \\
6,10 \& 15 \\
6 \\
2,6 \& 7\end{array}$ \\
\hline Ranidae & $\begin{array}{l}\text { Euphlyctis cyanophlyctis (Schneider) } \\
\text { Euphlyctis hexadactylus (Lesson) } \\
\text { Hoplobatrachus crassus (Jerdon) } \\
\text { Hoplobatrachus tigerinus (Daudin) } \\
\text { Fejervarya limnocharis (Boie. in Weig.) } \\
\text { Rana temporalis }{ }^{\star *} \text { (Günther) } \\
\text { Sphaeroteca breviceps (Schneider) } \\
\text { Tomopterna rolandae** (Dubois) }\end{array}$ & $\begin{array}{l}\text { Skittering Frog } \\
\text { Indian Pond Frog } \\
- \\
\text { Indian Bull Frog } \\
\text { Indian Cricket Frog } \\
- \\
\text { Indian Burrowing Frog } \\
\text { Indian Burrowing Frog }\end{array}$ & $\begin{array}{l}\text { ERMA-3a } \\
\text { ERMA-10a } \\
\text { ERMA-13a } \\
\text { ERMA-15a } \\
\text { ERMA-17a } \\
\text { ERMA-14a } \\
\text { ERMA-12a } \\
\text { ERMA-16a }\end{array}$ & $\begin{array}{l}\text { V,WB } \\
\text { V,WB } \\
\text { SF, V, WB } \\
\text { SF, V, WB } \\
\text { GL,DF, RF } \\
\text { DF,V } \\
\text { AH } \\
\text { SF,WB }\end{array}$ & $\begin{array}{l}2 \& 6 \\
2 \& 6 \\
6 \\
5,6 \& 13 \\
6,13,14 \& 15 \\
15 \\
6 \& 15 \\
6\end{array}$ \\
\hline Rhacophoridae & $\begin{array}{l}\text { Polypedates leucomystax }{ }^{* *} \text { (Gravenhorst) } \\
\text { Polypedates maculatus (Gray) }\end{array}$ & $\begin{array}{l}\text { East Asian Tree frog } \\
\text { Common Tree Frog }\end{array}$ & $\begin{array}{l}\text { ERMA-9a } \\
\text { ERMA-11a }\end{array}$ & $\begin{array}{l}\mathrm{SF}, \mathrm{RF} \\
\mathrm{AH}\end{array}$ & $\begin{array}{l}6 \& 15 \\
\text { In all localities }\end{array}$ \\
\hline
\end{tabular}

Table 2. List of Reptiles recorded from Nallamalais, Eastern Ghats, Andhra Pradesh

\begin{tabular}{|c|c|c|c|c|c|}
\hline Family & Taxon & Common Name & $\begin{array}{l}\text { Specimen } \\
\text { Code }\end{array}$ & $\begin{array}{l}\text { Habitat } \\
\text { Preference }\end{array}$ & Locality Code \\
\hline Testudinidae & Geochelone elegans* (Schoepff) & Indian Star Tortoise & ERMR-5a & $\mathrm{AH}$ & $4,6,8,9,15,16$ \\
\hline Gekkonidae & $\begin{array}{l}\text { Hemidactylus brooki (Gray) } \\
\text { Hemidactylus flaviviridis Ruppell } \\
\text { Hemidactylus frenatus Schlegel } \\
\text { Hemidactylus giganteus Stoliczka } \\
\text { Hemidactylus leschenaultii Duméril \& Bibron } \\
\text { Hemidactylus triedrus (Daudin) } \\
\text { Hemidactylus reticulatus Beddome }\end{array}$ & $\begin{array}{l}\text { Brook's Gecko } \\
\text { Northern house Gecko } \\
\text { Asian House Gecko } \\
\text { Giant Rock Gecko } \\
\text { Bark Gecko } \\
\text { Termite Gecko } \\
\text { Reticulate Gecko }\end{array}$ & $\begin{array}{l}\text { ERMR-2a } \\
\text { ERMR }-3 a \\
\text { ERMR }-30 a \\
\text { ERMR }-1 a \\
\text { ERMR }-4 a \\
\text { ERMR-7a } \\
\text { ERMR-17a }\end{array}$ & $\begin{array}{l}\text { SF,DF,BP } \\
\text { AH } \\
\text { V,DF } \\
\text { SF } \\
\text { SF,GL } \\
\text { SF,OF,GL } \\
\text { SF, GL,BP,RF }\end{array}$ & $\begin{array}{l}2,4,6,7,10,11,13 \\
6 \\
6,7 \\
1,6,7 \\
2,4,6,11,13 \\
1,4,6,13 \\
6,13,14\end{array}$ \\
\hline Agamidae & $\begin{array}{l}\text { Calotes versicolor (Daudin) } \\
\text { Calotes rouxii* Duméril \& Bibron } \\
\text { Psammophilus dorsalis (Gray) } \\
\text { Sitana ponticeriana Cuvier }\end{array}$ & $\begin{array}{l}\text { Common Garden Lizard } \\
\text { Roux's Forest Lizard } \\
\text { Peninsular Rock Agama } \\
\text { Fan-throated lizard }\end{array}$ & $\begin{array}{l}\text { ERMR-12a } \\
\text { ERMR-10a } \\
\text { ERMR-11a } \\
\text { ERMR-9a }\end{array}$ & $\begin{array}{l}\mathrm{AH} \\
\mathrm{SF}, \mathrm{V} \\
\mathrm{V} \\
\mathrm{AH}\end{array}$ & $\begin{array}{l}\text { In all localities } \\
3,5,12 \\
5,6 \\
\text { In all localities }\end{array}$ \\
\hline Chamaeleonidae & Chamaeleo zeylanicus Laurenti & Indian Chameleon & ERMR-13a & SF,DF & $5,6,7 \& 8$ \\
\hline Scincidae & $\begin{array}{l}\text { Lygosoma guentheri } i^{* \star} \text { (Peters) } \\
\text { Mabuya beddomii }{ }^{\star *} \text { (Jerdon) } \\
\text { Mabuya carinata (Schneider) } \\
\text { Mabuya macularia (Duméril \& Bibron) }\end{array}$ & $\begin{array}{l}\text { Beddomes South Indian Skink } \\
\text { Common Skink } \\
\text { Bronze Grass Skink }\end{array}$ & $\begin{array}{l}\text { ERMR-43a } \\
\text { ERMR-21a } \\
\text { ERMR-15a } \\
\text { ERMR-16a }\end{array}$ & $\begin{array}{l}\text { V } \\
\text { SF,V } \\
\text { DF,V } \\
\text { AH }\end{array}$ & $\begin{array}{l}6 \\
1,3 \\
\text { In all localities } \\
2,6,8,9,10,11,12\end{array}$ \\
\hline Lacertidae & $\begin{array}{l}\text { Ophisops minor nictans Arnold } \\
\text { Ophisops jerdoni (Blyth) }\end{array}$ & $\begin{array}{l}\text { Beddome's Cabrita lizard } \\
\text { Jerdon's Snake-eye }\end{array}$ & $\begin{array}{l}\text { ERMR-8a } \\
\text { ERMR-18a }\end{array}$ & $\begin{array}{l}\text { SF,OF,DF,RF } \\
\text { SF,OF,DF,RF }\end{array}$ & $\begin{array}{l}1,6,11,15 \\
6,15,16\end{array}$ \\
\hline Varanidae & Varanus bengalensis (Linnaeus) & Indian Monitor Lizard & ERMR-26a & $\mathrm{AH}$ & In all localities \\
\hline Typhlopidae & Ramphotyphlops braminus (Daudin) & Common Worm or Blind Snake & ERMR-19a & SF,DF,RF & $6,12,15$ \\
\hline Boidae & $\begin{array}{l}\text { Gongylophis conica (Schneider) } \\
\text { Eryx johnii (Russell) } \\
\text { Python molurus (S) (Linnaeus) }\end{array}$ & $\begin{array}{l}\text { Russell's Earth Boa } \\
\text { John's Earth Boa } \\
\text { Indian Rock Python }\end{array}$ & $\begin{array}{l}\text { ERMR-14a } \\
\text { ERMR-22a } \\
-\end{array}$ & $\begin{array}{l}\text { SF,OF,DF,GL } \\
\text { SF,DF } \\
\text { SF }\end{array}$ & $\begin{array}{l}2,4,6,7,10,11,13 \\
2,4,6 \\
6\end{array}$ \\
\hline Elapidae & $\begin{array}{l}\text { Bungarus caeruleus (Schneider) } \\
\text { Naja naja (Linnaeus) }\end{array}$ & $\begin{array}{l}\text { Common Indian Krait } \\
\text { Indian Cobra }\end{array}$ & $\begin{array}{l}\text { ERMR-24a } \\
\text { ERMR-33a }\end{array}$ & $\begin{array}{l}\text { SF,OF,GL } \\
\mathrm{AH}\end{array}$ & $\begin{array}{l}2,6,13 \\
\text { In all localities }\end{array}$ \\
\hline Colubridae & $\begin{array}{l}\text { Ahaetulla nasutus isabellinus** (Wall) } \\
\text { Amphiesma stolata* (Linnaeus) } \\
\text { Argyrogena fasciolatus (Shaw) } \\
\text { Boiga trigonata (Bechstein) } \\
\text { Boiga forsteni* (Duméril , Bibron \& Duméril) } \\
\text { Cerberus rhynchops* (S) (Schneider) } \\
\text { Coelognathus helena helena (Daudin) }\end{array}$ & $\begin{array}{l}\text { Common Brown Vine Snake } \\
\text { Buffstriped Keelback } \\
\text { Banded Racer } \\
\text { Indian Gamma } \\
\text { Forsten's Cat Snake } \\
\text { Dog faced Water Snake } \\
\text { Trinket Snake }\end{array}$ & $\begin{array}{l}\text { ERMR-6a } \\
\text { ERMR-27a } \\
\text { ERMR-28a } \\
\text { ERMR-37a } \\
\text { ERMR-20a } \\
- \\
\text { ERMR-32a }\end{array}$ & $\begin{array}{l}\text { V } \\
\text { V,GL } \\
\text { SF,V } \\
\text { SF,DF,V } \\
\text { SF } \\
\text { V } \\
\text { SF,DF,GL }\end{array}$ & $\begin{array}{l}3 \\
6,13 \\
6,12 \\
6,7 \\
9 \\
6 \\
3,6,13\end{array}$ \\
\hline
\end{tabular}




\begin{tabular}{|c|c|c|c|c|c|}
\hline Family & Taxon & Common Name & $\begin{array}{l}\text { Specimen } \\
\text { Code }\end{array}$ & $\begin{array}{l}\text { Habitat } \\
\text { Preference }\end{array}$ & Locality Code \\
\hline Viperidae & $\begin{array}{l}\text { Dendrelaphis tristis (Daudin) } \\
\text { Enhydris enhydris (S) (Schneider) } \\
\text { Lycodon aulicus (Linnaeus) } \\
\text { Lycodon striatus* (Shaw) } \\
\text { Lycodon travancoricus* (Beddome) }^{*} \text { Liopeltis calamaria** (Gunther) }_{\text {Macropisthodon plumbicolor }}^{\star} \text { (Cantor) } \\
\text { Oligodon arnensis (Shaw) } \\
\text { Oligodon taeniolatus (Jerdon) } \\
\text { Ptyas mucosa (Linnaeus) } \\
\text { Sibynophis subpunctatus }{ }^{\star *} \text { (Duméril \& Bibron) } \\
\text { Xenochrophis piscator (S) (Lacepede) } \\
\text { Daboia russelii (Shaw \& Nodder) } \\
\text { Echis carinatus (Schneider) } \\
\text { Trimeresurus gramineus* (Shaw) }\end{array}$ & $\begin{array}{l}\text { Common Indian Bronze back } \\
\text { Common Smooth Water Snake } \\
\text { Common Wolf Snake } \\
\text { Barred Wolf Snake } \\
\text { Travancore Wolf Snake } \\
\text { - } \\
\text { Green keel back } \\
\text { Banded Kukri Snake } \\
\text { Streaked Kukri Snake } \\
\text { Indian Rat Snake } \\
\text { Cantor's Black-headed Snake } \\
\text { Checkered Keel back } \\
\text { Russel's Viper } \\
\text { Saw - Scaled Viper } \\
\text { Green Pit Viper }\end{array}$ & $\begin{array}{l}\text { ERMR-25a } \\
- \\
\text { ERMR-35a } \\
\text { ERMR-44a } \\
\text { ERMR-38a } \\
\text { ERMR-29a } \\
\text { ERMR-36a } \\
\text { ERMR-41a } \\
\text { ERMR-42a } \\
\text { ERMR-39a } \\
\text { ERMR-40a } \\
- \\
\text { ERMR-34a } \\
\text { ERMR-23a } \\
\text { ERMR-31a }\end{array}$ & $\begin{array}{l}\text { SF,DF,GL } \\
\text { V,WB } \\
\text { SF } \\
\text { SF,GL } \\
\text { SF,GL } \\
\text { SF } \\
\text { SF,DF,V } \\
\text { V,DF,BP } \\
\text { V,DF,BP } \\
\text { AH } \\
\text { V } \\
\text { SF,V } \\
\text { AH } \\
\text { SF,GL } \\
\text { SF,DF }\end{array}$ & $\begin{array}{l}2,3,6,13 \\
2 \\
6 \\
6,13 \\
6 \& 13 \\
6 \\
2,3 \& 6 \\
6,11 \& 13 \\
4,6 \& 11 \\
\text { In all localities } \\
6 \\
6 \\
5,6,8,13 \& 15 \\
7,8 \& 13 \\
6\end{array}$ \\
\hline
\end{tabular}

New record from the Nallamalais *; New record from the State ${ }^{* *}$; (S) - Sighted species

For locality code details of each species refer figure - 1.

SF - Scrub forest; OF - Open forest; GL- Grassland; DF - Dense forest; V - Riparian forest; WB - Water bodies; BP - Bamboo Patches; RF - Riparian

Forest; AH - All habitats

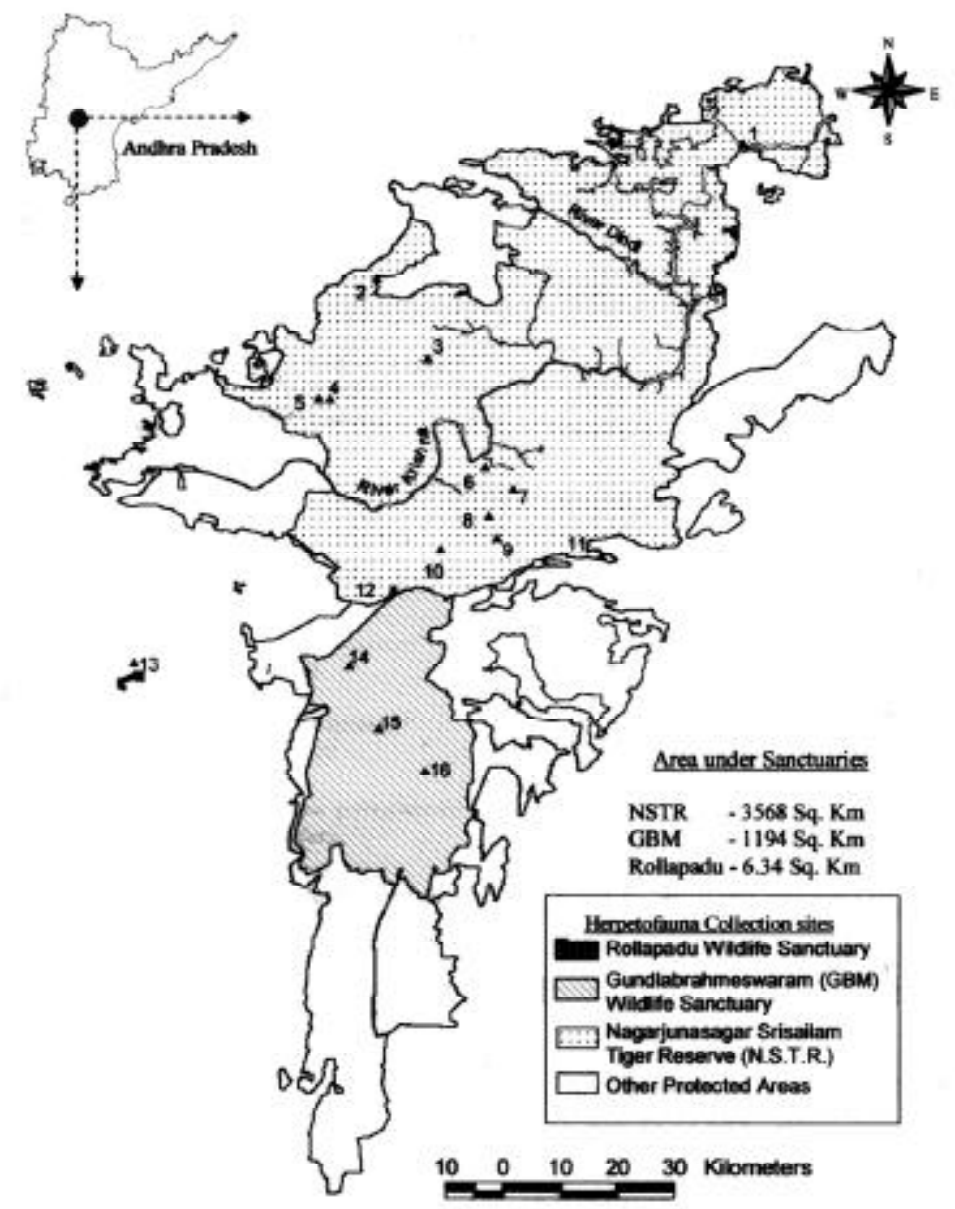

Figure 1. Map of Nallamalai Hills, Eastern Ghats, Andhra Pradesh showing collection sites of Herpetofauna in three Wildlife Sanctuaries.

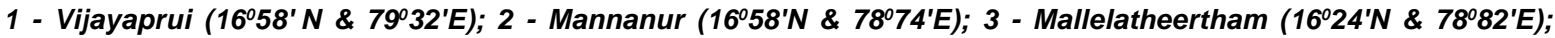

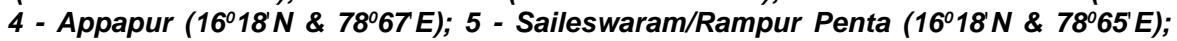

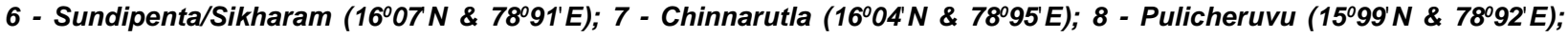

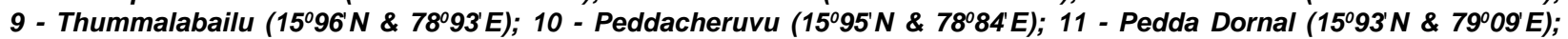

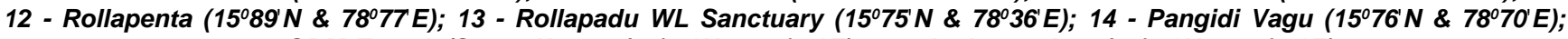

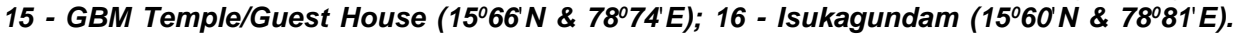

